\title{
Digenea and Acanthocephala of Elasmobranch Fishes from the Southern Coast of Brazil
}

\author{
Marcelo Knoff $/{ }^{++}$, Sérgio Carmona de São Clemente*/++, \\ Roberto Magalhães Pinto/ ${ }^{++}$, Delir Corrêa Gomes $/{ }^{+}+{ }^{+}$
}

\begin{abstract}
Laboratório de Helmintos Parasitos de Vertebrados, Departamento de Helmintologia, Instituto Oswaldo CruzFiocruz, Av. Brasil 4365, 21045-900 Rio de Janeiro, RJ, Brasil *Faculdade de Veterinária, Universidade Federal Fluminense, Niterói, RJ, Brasil
\end{abstract}

New records for helminth species recovered from elasmobranch fishes in Brazil are established. Digenean and acanthocephalan parasites of elasmobranch fishes are reported from the southern coast of Brazil: Otodistomum veliporum (Creplin, 1837) Stafford, 1904 (Digenea: Azygiidae) in the stomach and spiral valve of Dipturus trachydermus and in the spiral valve of Squatina sp. Cystacanths and juveniles of the acanthocephalans Corynosoma australe Johnston, 1937 and Corynosoma sp., in the spiral valve of Squatina sp., Galeorhinus galeus and Hexanchus griseus and in the stomach of Squalus megalops; a juvenile of Gorgorhynchus sp., in the spiral valve of Sphyrna zygaena. Dipturus trachydermus and Squatina sp. are new host records for O. veliporum. Digeneans and acanthocephalans are reported for the first time parasitizing elasmobranch fishes in Brazil.

Key words: Digenea - Acanthocephala - new records - elasmobranch fishes - Brazil

Helminths recovered from Brazilian elasmobranch fishes have been previously reported by Rego et al. (1974), Rego (1977), Vicente et al. (1985), São Clemente and Gomes (1989a, b, 1992), São Clemente et al. (1991), Vicente and Pinto (1999) and Knoff et al. (2001). The present study reports a digenetic trematode and three acanthocephalans parasitizing elasmobranchs, that are referred as new host records for the helminth species.

\section{MATERIALS AND METHODS}

A total of 307 elasmobranch fishes were examined. In November 1984, June 1985, and July 1986, 217 elasmobranch fishes: 6 Notorynchus cepedianus (Péron, 1807) (90-130 cm of total lengthtl), 14 Squalus megalops (Macleay, 1881) (45-59 $\mathrm{cm}$ tl), 37 Mustelus canis (Mitchill, 1815) (70.5-113 $\mathrm{cm} \mathrm{tl),35} \mathrm{M.} \mathrm{schmitti} \mathrm{Springer,} 1939(56-98 \mathrm{~cm} \mathrm{tl}), 37$ Galeorhinus galeus (Linnaeus, 1758) (86-146 cm tl), 7 Carcharhinus brachyurus (Günther, 1870) (80-108 cm tl), 16 Sphyrna zygaena (Linnaeus, 1758)

Financial support: CNPq Proc. no. 571491/97-9

${ }^{+}$Corresponding author. Fax: +55-21-2598.4363. E-mail: dcgomes@gene.dbbm.fiocruz.br

${ }^{++} \mathrm{CNPq}$ research fellows, Proc. no. 143277/97-9, 302459/88-0, 300374/80-1 and 303124/89-0, respectively.

Received 9 February 2001

Accepted 3 August 2001
(81-147 cm tl), 5 S. lewini (Linnaeus, 1758) (75-165 $\mathrm{cm}$ tl), 20 Squatina guggenheim Marini, 1936 (64$87 \mathrm{~cm} \mathrm{tl}), 26$ specimens of Squatina sp. (81-125 cm tl), 12 Raja castelnaui Miranda-Ribeiro, 1907 (70$103 \mathrm{~cm} \mathrm{tl}), 1$ Dasyatis say (Lesueur, 1817) $(58 \mathrm{~cm} \mathrm{tl})$ and 1 D. centroura (Mitchill, 1815) $(103 \mathrm{~cm} \mathrm{tl})$ were captured off the coast of State of Rio Grande do Sul $\left(30^{\circ} 40^{\prime} \mathrm{S}-33^{\circ} 40^{\prime} \mathrm{S}\right.$ and $50^{\circ} 40^{\prime} \mathrm{W}-53^{\circ} 20^{\prime} \mathrm{W} ; 12-100 \mathrm{~m}$ depth) by professional fisherman of the oceanographic ship Atlântico Sul. In March 1998, 46 elasmobranch fishes: 1 Hexanchus griseus (Bonnaterre, 1788) $(132 \mathrm{~cm} \mathrm{tl}), 7$ Heptranchias perlo (Bonnaterre,1788) (87-107.4 cm tl), 16 Squalus sp. (41-67 $\mathrm{cm}$ tl), 9 Scyliorhinus haeckelii (Miranda-Ribeiro, 1907) (41.5-54.5 cm tl), 5 Carcharhinus signatus (Poey, 1868) $(120-150 \mathrm{~cm} \mathrm{tl})$ and 8 Dipturus trachydermus (Krefft \& Stehmann, 1975) (133.5-176 $\mathrm{cm} \mathrm{tl})$ were captured at about 125 miles off the coast of State of Paraná (25 $50^{\circ} \mathrm{S}-25^{\circ} 52^{\prime} \mathrm{S}$ and $45^{\circ} 23^{\prime} \mathrm{W}$ $45^{\circ} 25^{\prime} \mathrm{W}$; $200-500 \mathrm{~m}$ depth) by professional fishermen of the Icanhema VI fish boat. In March 1999, more 44 elasmobranch fishes: 4 Isurus oxyrhinchus Rafinesque, $1810(165-221 \mathrm{~cm} \mathrm{tl}), 30$ Prionace glauca (Linnaeus, 1758) (206-287 cm tl), 2 Carcharhinus signatus $(143-190 \mathrm{~cm} \mathrm{tl}), 2 C$. longimanus (Poey, 1861) $(170-209 \mathrm{~cm} \mathrm{tl}), 1 C$. obscurus (Lesueur, 1818) ( $247 \mathrm{~cm} \mathrm{tl}$ ) and 5 Sphyrna zygaena $(190-250 \mathrm{~cm} \mathrm{tl})$ were captured about $50 \mathrm{~m}$ depth, 190 miles off the coast of State of Santa Catarina $\left(27^{\circ} 08^{\prime} \mathrm{S}-28^{\circ} 38^{\prime} \mathrm{S}\right.$ and $\left.45^{\circ} 30^{\prime} \mathrm{W}-46^{\circ} 53^{\prime} \mathrm{W}\right)$ by professional fishermen of the Kiyomã tuna fish boat. On board, their stomachs and spiral valves were collected, labelled and preserved in ice, be- 
fore examination. Parasites were collected, fixed, stained and mounted according to the methods described in Amato et al. (1991). The systematic organization of the parasites was based on Yamaguti (1971) and Brooks et al. (1985a, b) (Digenea), and on Yamaguti (1963), Golvan $(1959,1969)$, Petrochenko (1971a, b), and Amin (1985, 1987) (Acanthocephala). The prevalence, intensity and mean intensity of infection are indicated in accordance to Bush et al. (1997). The drawings were made with a camera lucida connected to an Olympus $\mathrm{BH}-2$ microscope. All measurements are in millimeters unless otherwise indicated; ranges of measurements are followed by mean values (when indicated) within parentheses. Voucher specimens are deposited in the Coleção Helmintológica do Instituto Oswaldo Cruz (CHIOC), Fiocruz, Rio de Janeiro, RJ, Brazil. At least one specimen of each host species was deposited as voucher host, simbiotype sensu Brooks (1993), in the Coleção Ictiológica do Instituto de Pesca, Santos, SP, Brazil: P. glauca no. IP1967; I. oxyrhinchus no. IP 1968; S. zygaena no. IP 1969; C. longimanus no. 1970; $C$. obscurus no. IP 1971, are additional specimens to those listed elsewhere (Knoff et al. 2001).

\section{RESULTS}

Data are based on specimens recovered in the present investigation and are depicted in the Tables. Taking into account that the referred species are well known, morphometrics refer to the characters considered most important to its diagnosis.
DIGENEA

Hemiuriformes Travassos et al., 1969

Azygiidae Lühe, 1909

Otodistomum veliporum (Creplin, 1837) Stafford, 1904

(Figs 1-4, Table I)

Remarks - The systematics of the genus Otodistomum Stafford, 1904 has been of concern to different authors. Species of this taxon have been reported since the begining of the 19th century, from various marine species of rays and sharks collected from sub-tropical, temperate, sub-Artic and sub-Antartic regions (Manter 1926, Dollfus 1937, Miller 1941, Van Cleave \& Vaughn 1941, Kay 1947, Skrjabin \& Guschanskaya 1958, Caballero \& Caballero 1969, Yamaguti 1971, Gibson 1976a, b, Threlfall \& Carvajal 1986, Zdzitowiecki \& Pisano 1996).

The systematics of these digeneans parasitizing elasmobranchs was discussed by Manter (1926), Dollfus (1937), Van Cleave \& Vaughn (1941) and Gibson (1976a, b) based on differences related to body dimensions, extent and form of uterine branches, extent of vitellaria, ratio between oral and ventral suckers, length and thickness of the egg. The three later authors considered two distinct species of the genus Otodistomum from elasmobranch hosts: O. veliporum (Creplin, 1937) Stafford, 1904 mainly from sharks and $O$. cestoides (Van Beneden, 1871) Stafford, 1904 mainly from rays, based on differences in the egg. Dawes (1947), Rees (1953), Skrjabin and Guschanskaya (1958) and

TABLE I

Data on Otodistomum veliporum collected from elasmobranch fishes (present study)

\begin{tabular}{lcc}
\hline & Imature specimen & Adult specimens \\
\hline Body & $9.54 \times 1.48$ & $12.3-28.1(17.6) \times 1.8-3.7(2.5)$ \\
Oral sucker & $0.50 \times 0.56$ & $0.54-1.20(0.79) \times 0.72-1.20(0.91)$ \\
Acetabulum & $0.84 \times 0.86$ & $0.84-1.84(1.19) \times 1.14-1.90(1.41)$ \\
Pharynx & $0.28 \times 0.30$ & $0.24-0.56(0.38) \times 0.34-0.56(0.42)$ \\
Testes anterior $\quad$ posterior & $0.23 \times 0.18$ & $0.58-1.10(0.81) \times 0.72-1.18(0.89)$ \\
Cirrus pouch & $0.26 \times 0.20$ & $0.66-1.20(0.85) \times 0.66-0.98(0.81)$ \\
Seminal vesicle & $0.37 \times 0.20$ & $0.50-1.54(0.79)-0.34-0.58(0.43)$ \\
Ovary & $0.62 \times 0.08$ & $0.92-2.24(1.41) \times 0.20-0.34(0.25)$ \\
Eggs & $0.12 \times 0.12$ & $0.32-0.64(0.42) \times 0.40-0.84(0.55)$ \\
Egg-shell wall & - & $0.072-0.096(0.084) \times 0.048-0.060(0.052)$ \\
Hosts & - & $0.002-0.006$ \\
Site of infection & Squatina sp. & Dipturus trachydermus \\
Locality & Spiral valve & Stomach and spiral valve \\
Prevalence $(\%)$ & RS & PR \\
Intensity of infection & 3.8 & 12.5 \\
Voucher CHIOC no. & 1 & 4 \\
\hline RS Costo & 34262 & 33980 a-d
\end{tabular}

RS: Coast of the State of Rio Grande do Sul; PR: Coast of the State of Paraná; CHIOC: Coleção Helmintológica do Instituto Oswaldo Cruz; measurements in $\mathrm{mm}$ 
Brinkmann $\mathrm{Jr}$ (1975) suggested that $O$. cestoides should be considered a synonym of $O$. veliporum. According to Brinkman Jr (1988) life-cycles of the parasites should be investigated to support this proposition. Nevertheless, we consider our specimens to be $O$. veliporum based on the fact that the differences now observed in both species may be related to the size of body, compressing conditions, different hosts, and egg thickness that is $2-6 \mu \mathrm{m}$ in our specimens, compared to 6-10 $\mu \mathrm{m}$ previously reported for O. veliporum (Dollfus 1937, Rees 1953, Skrjabin \& Guschanskaya 1958, Caballero \& Caballero 1969, Yamaguti 1971); and 3-5.3 $\mu \mathrm{m}$ for $O$. cestoides (Manter 1926, Dollfus 1937, Miller 1941, Van Cleave \& Vaughn 1941, Skrjabin \& Guschanskaya 1958, Yamaguti 1971, Gibson 1976a, Threlfall \& Carvajal 1986).

This species was reported as $O$. cestoides from Raja spp., R. flavirostris (= Dipturus flavirostris) and Psammobatis scobina in South America (Falkland Islands and Chilean Coast) by Dollfus (1937), Gibson (1976a) and Threlfall and Carvajal (1986) and from Bathyraja eatonii and B. murrayi in the Indian Ocean by Zdzitowiecki and Pisano (1996).

Dipturus trachydermus and Squatina sp. are two new hosts records for the O. veliporum. This is the first report of a digenetic trematode in elasmobranch fishes in Brazil.

\section{ACANTHOCEPHALA}

Palaeacanthocephala Meyer, 1931

Polymorphida Petrochenko, 1956

Polymorphidae Meyer, 1931

Corynosoma australe Johnston, 1937

(Figs 5-7, Table II)

Corynosoma sp.

(Figs 8-11, Table II)
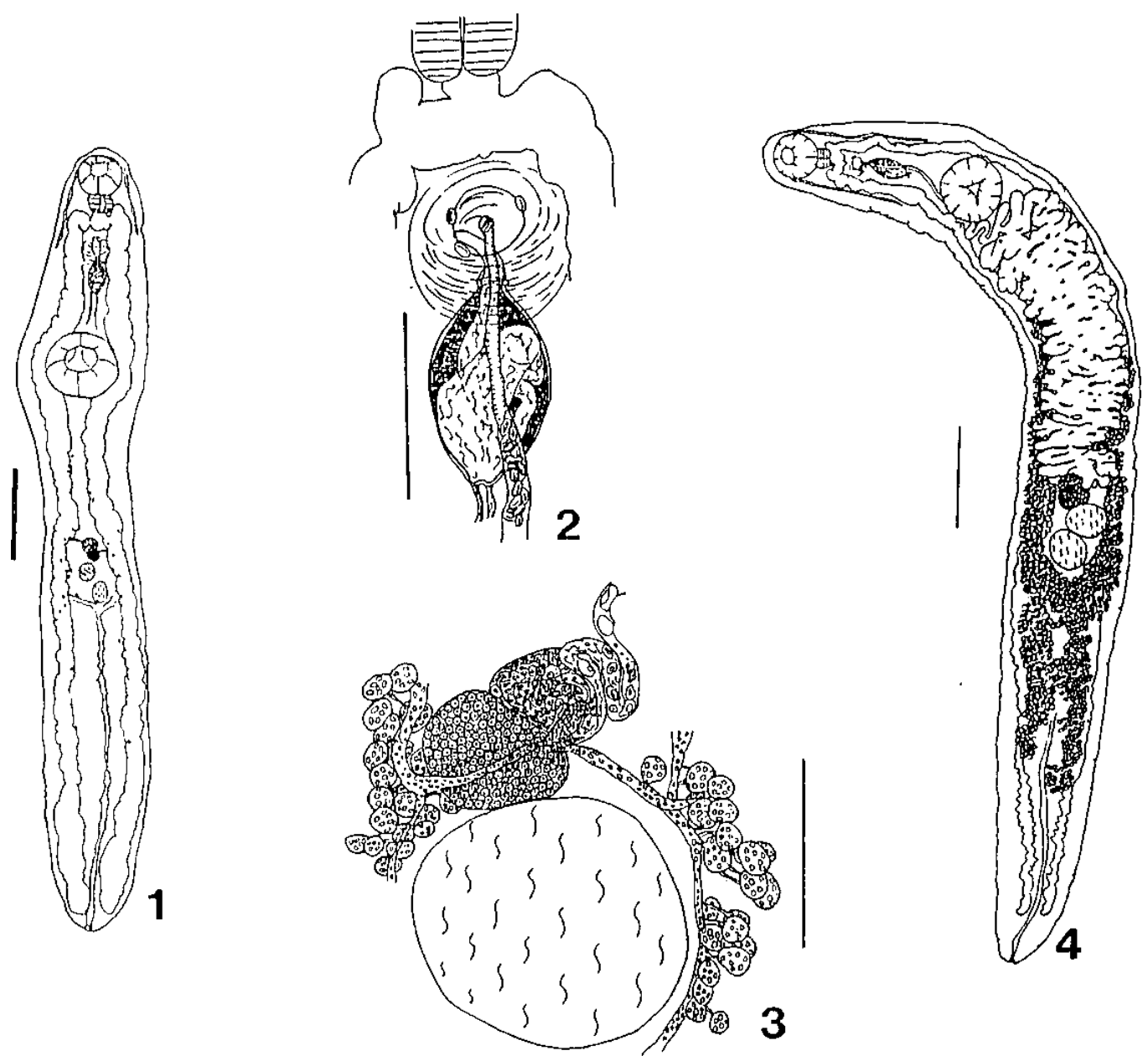

Otodistomum veliporum - Fig. 1: immature specimen in Squatina $\mathrm{sp}$., total, ventral view (Bar = $1 \mathrm{~mm})$. Fig. 2: terminal genitalia (adult in Dipturus trachydermus), ventral view $(B a r=1 \mathrm{~mm}$ ). Fig. 3: ovarian complex (adult), ventral view (Bar $=0.5 \mathrm{~mm})$. Fig. 4: total (adult), ventral view $($ Bar $=3 \mathrm{~mm})$ 
Remarks - The species of Corynosoma reported here are probably accidental parasites of elasmobranch fishes, since they are known to use mammals and birds as definitive hosts (Schmidt 1985). The identification of $C$. australe was obtained on the basis of morphometrics data related mainly to the number of hooks and number of rows of the proboscis (see Petrochenko 1971b). C. australe was originally described parasitizing Neophoca cinerea and was also reported from other marine mammals from Australia (Golvan 1959, Yamaguti 1963, Petrochenko 1971b, Smales 1986). In South America, C. australe had been reported in teleost fishes from Pacific (Peru) to Atlantic waters (Uruguay) (Vergara \& George-Nascimento 1982, Zdzitowiecki 1989, Cremonte \& Sardella 1997,
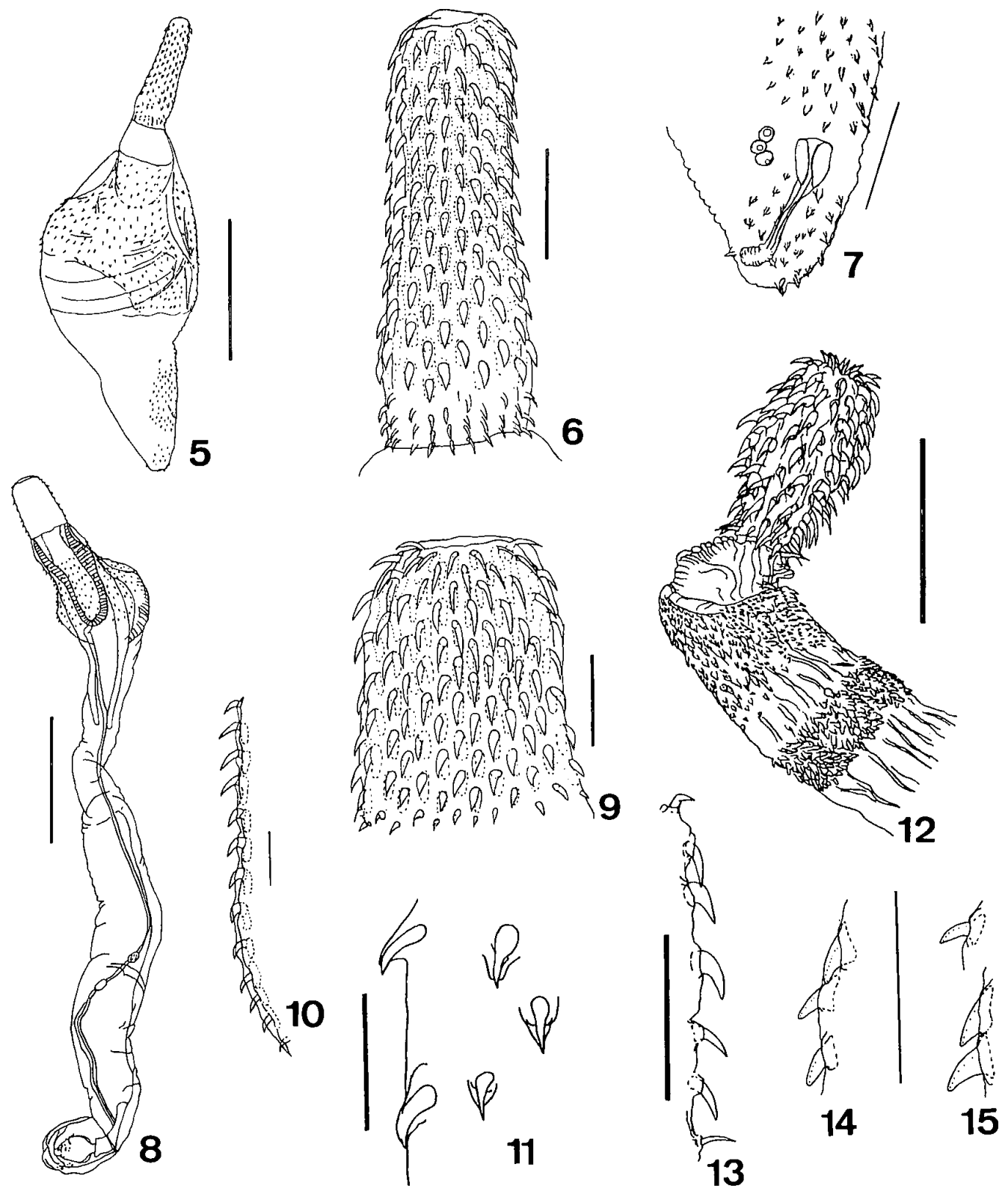

Corynosoma australe - Fig. 5: female cystacanth in Squatina sp., total, lateral view $(\mathrm{Bar}=1 \mathrm{~mm})$. Fig. 6: proboscis, ventral view $(B a r=0.2 \mathrm{~mm})$. Fig. 7: female cystacanth, posterior portion, lateral view $($ Bar $=0.2 \mathrm{~mm})$. Corynosoma sp. - Fig. 8: juvenile male, total, ventral view $(B a r=1.5 \mathrm{~mm})$. Fig. 9: proboscis, ventral view $(B a r=0.2 \mathrm{~mm})$. Fig. 10: hooks of proboscis, lateral view $(B a r=0.2 \mathrm{~mm})$. Fig. 11: trunk spines $($ Bar $=0.1 \mathrm{~mm})$. Gorgorhynchus sp. - Fig. 12: portion of trunk and proboscis, lateral view $(B a r=0.5 \mathrm{~mm})$. Fig. 13: hooks of proboscis, lateral view $(\mathrm{Bar}=0.25 \mathrm{~mm})$. Fig. 14: trunk spines, first area, lateral view $($ Bar $=0.1 \mathrm{~mm})$. Fig. 15: trunk spines, second area, lateral view $($ Bar $=0.1 \mathrm{~mm})$ 
Tanzola et al. 1997, Oliva 1999). In Brazil these acanthocephalans occurred in teleost fishes: Corynosoma sp. in Pomatomus saltator from the coast of the State of Rio de Janeiro and C. australe in Micropogonias furnieri from the coast of the State of Rio Grande do Sul (Rego et al. 1983, Pereira Jr \& Neves 1993). The morphology of the other Corynosoma sp. (juvenile form), considered here is similar to C. reductum (Linstow, 1905) Raillet \& Henry, 1907 but the evagination of the proboscis did not permit the proper species determination. This is the first occurrence of specimens of Corynosoma in elasmobranch fishes.
Echinorhynchida Southwell \& MacFie, 1925

Rhadinorhynchidae Travassos, 1923

Gorgorhynchus sp.

(Figs 12-15, Table II)

Remarks - The juvenile of Gorgorhynchus sp. presents the typical generic characteristics related to the form of the body and the proboscis, the distribution of trunk spines and length of proboscis sheat. Nevertheless, our specimens could neither be identified as Gorgorhynchus trachinotus Noronha et al.,1986, the only Brazilian species of the genus parasitizing the intestine of a teleost fish Trachinotus goodei Jordan and Evermann, 1896

TABLE II

Data on Acanthocephala species collected from elasmobranch fishes (present study)

\begin{tabular}{lccc}
\hline & Corynosoma australe & Corynosoma sp. & Gorgorhynchus sp. (juvenile form) \\
\hline Body & $2.97 \times 1.05$ & $8.92 \times 1.05$ & $7.174 \times 0.408$ \\
Proboscis (long) & 0.73 & 0.64 & 0.560 \\
anterior region (wide) & 0.15 & 0.36 & 0.182 \\
median region (wide) & 0.18 & 0.40 & 0.238 \\
basal region (wide) & 0.21 & 0.43 & 0.140
\end{tabular}

Hooks

18 rows of 12-14 hooks each

Basal Root

Midle and anterior Root

Trunk spines

Genital spines

Ovijector and bell

Hosts

Site of infection

Locality

Prevalence (\%)

Intensity or mean intensity*

Voucher CHIOC no.
0.018-0.007

Squatina sp.; Squalus megalops; Galeorhinus galeus; Hexanchus griseus

Spiral valve; stomach; spiral valve; spiral valve

RS; RS; RS; PR

$3.8 ; 7.1 ; 2.7 ; 100$

$$
2 ; 1 ; 3 * ; 4
$$

34283 a-b; 34284 b; 34286; 34280 a-d
12 partially extroverted rows of 12-14 hooks each

$0.018-0.032 \times 0.003-0.007$ $0.014-0.018 \times 0.003-0.007$

$0.046-0.072 \times 0.010-0.014$ 0.032-0.054 x 0.010-0.014

$0.014-0.021 \times 0.010$
9 partially extroverted rows of 13-14 hooks each

$0.0540-0.0612 \times 0.0108-0.0180$ $0.0144-0.0180 \times 0.0144-0.0216$

0.0720-0.0936 x 0.0216-0.0396 0.0108 x 0.0216-0.0468

0.0288-0.0396 x 0.0180-0.0288 1st area: 20 rows of 20-22 spines each 2nd area: 12 rows of 18-20 spines each

Sphyrna zygaena

Squatina sp.; Squalus megalops;

Galeorhinus galeus

Spiral valve; stomach; spiral valve

Spiral valve

RS; RS; RS

$\mathrm{SC}$

$3.8 ; 7.1 ; 5.4$

20

$1 ; 1 ; 1.5^{*}$

1

34282; 34284 a; 34285,

$34287 \mathrm{a}-\mathrm{b}$

RS: Coast of the State of Rio Grande do Sul; PR: Coast of the State of Paraná; SC: Coast of the State of Santa Catarina; CHIOC: Coleção Helmintológica do Instituto Oswaldo Cruz; *morphometric data of C. australe and Corynosoma sp. were obtained from a female cystacanth and a juvenile male, respectively, both from Squatina sp. of RS; measurements in $\mathrm{mm}$ 
(Noronha et al. 1986) nor as any other described species (Golvan 1969, Petrochenko 1971a). This is the first record of a species of Gorgorhynchus in an elasmobranch host.

\section{ACKNOWLEDGMENTS}

To Dr Dely Noronha from the CHIOC, Fiocruz, Rio de Janeiro, for the drawings of Corynosoma spp. To Dr Carolus Maria Vooren from the Universidade do Rio Grande, Rio Grande do Sul, for the identification of fishes captured between the years 1984-1986, to Drs Alberto Ferreira Amorim and Carlos Arfelli from the Instituto de Pesca, Santos, State of São Paulo, for the identification of fishes captured between the years 1998-1999 and to the fishermen of the research ship Atlântico Sul of the Fundação Universidade Federal do Rio Grande, and also the fishing boats Icanhema VI and Kyiomã from Santos both for the help during capture of hosts.

\section{REFERENCES}

Amato JFR, Boeger WA, Amato SB 1991. Protocolos para Laboratório - Coleta e Processamento de Parasitos de Pescado, Imprensa Universitária, Universidade Federal Rural do Rio de Janeiro, Seropédica, $81 \mathrm{pp}$.

Amin OM 1985. Classification. In DWT Crompton, BB Nickol (eds), Biology of Acanthocephala, Cambridge University Press, London, 519 pp.

Amin OM 1987. Key to the families and subfamilies of Acanthocephala, with the erection of a new class (Polyacanthocephala) and a new order (Polyacanthorhynchida). J Parasitol 73: 1216-1219.

Brinkman Jr A 1975. Trematodes from Greenland. Medd Gronland 205: 1-88.

Brinkman Jr A 1988. Presence of Otodistomum sp. metacercariae in Norwegian marine fishes. Sarsia 73: 7982.

Brooks DR 1993. Extending the symbiotype concept to host voucher specimens. J Parasitol 79: 631-633.

Brooks DR, O'Grady RT, Glen DR 1985a. Phylogenetic analysis of the Digenea (Platyhelminthes: Cercomeria) with comments on their adaptative radiation. Can J Zool 63: 411-443.

Brooks DR, O'Grady RT, Glen DR 1985b. The phylogeny of the Cercomeria Brooks, 1982 (Platyhelminthes). Proc Helminthol Soc Wash 52: 1-20.

Bush AO, Lafferty KD, Lotz JM, Shostak AW 1997. Parasitology meets ecology on its own terms: Margolis et al. revisited. J Parasitol 83: 575-583.

Caballero EC, Caballero GR 1969. Études des trématodes récoltés par Howard A. Winter chez les poissons marins de l'Ócean Pacifique du Mexique et des États Unis. J Fish Res Bd Can 26: 957-963.

Cremonte F, Sardella NH 1997. The parasite fauna of Scomber japonicus Houttwyn, 1782 (Pisces: Scombridae) in two zones of Argentine Sea. Fisher Res 31: 1-9.

Dawes B 1947. The Trematoda of British Fishes, Royal Society, London, $364 \mathrm{pp}$.

Dollfus RP 1937. Parasitologia Mauritanica. Helmintha (III). Trématodes de sélaciens et de chéloniens. Bull Com Étud Hist Sci Afr Occ Franç 19: 397-520.
Gibson DI 1976a. Monogenea and Digenea from fishes. Discov Rep 36: 179-266.

Gibson DI 1976b. The "Otodistomum veliporumcestoides" problem. Norw J Zool 24: 468.

Golvan YJ 1959. Acanthocéphales du genre Corynosoma Lühe, 1904 parasite de mammifères d'Alaska et de Midway. Ann Parasitol Hum Comp 34: 288-321.

Golvan YJ 1969. Systematique des Acanthocephales (Acanthocephala Rudolphi, 1801). L'Ordre des Paleacanthocephala Meyer, 1931. La super-familie des Echinorhynchoidea (Cobbold, 1876) Golvan et Houin, 1963. Memo Mus Nat Hist Nat Paris, sér A, zool, 57: 1-373.

Kay MW 1947. Otodistomum plicatum n. sp. (Trematoda, Digenea) from Hexanchus griseus (Bonnaterre). Ohio J Sci 47: 79-83.

Knoff M, São Clemente SC, Pinto RM, Gomes DC 2001. Nematodes of elasmobranch fishes from the coast of Brazil. Mem Inst Oswaldo Cruz. 96: 81-87.

Manter HW 1926. Some North American fish trematodes. III. Illinois Biol Monographs 10: 1-138.

Miller MJ 1941. A critical study of Stafford's report on "Trematodes of Canadian fishes" based on his trematode collection. Canadian J Res (sect d) 19: 28-52.

Noronha D, Vicente JJ, Pinto RM, De Fábio SP 1986. Gorgorhynchus trachinotus n.sp. and new host records for Dollfusentis chandleri Golvan, 1969 (Paleacanthocephala, Echinorhynchoidea). Mem Inst Oswaldo Cruz 81: 145-148.

Oliva ME 1999. Metazoan parasites of the jack mackerel Trachurus murphi (Teleostei, Carangidae) in a latidudinal gradient from South America (Chile and Peru). Parasite 6: 223-230.

Pereira Jr J, Neves LFM 1993. Corynosoma australe Johnston, 1937 (Acanthocephala, Polymorphidae) em Micropogonias furnieri (Desmarest, 1823) (Perciformes, Scianidae) do litoral do Rio Grande do Sul. Comum Mus Ciênc PUCRS sér zool 6: 51-61.

Petrochenko VI 1971a. Acanthocephala of Domestic and Wild Animals, Vol. I, edited by KI Skrjabin, Acad Sci URSS, translated from Russian, Israel Program for Scientific Translations, Jerusalem, $465 \mathrm{pp}$.

Petrochenko VI 1971b. Acanthocephala of Domestic and Wild Animals, Vol. II, edited by KI Skrjabin, Acad Sci URSS, translated from Russian, Israel Program for Scientific Translations, Jerusalem, 478 pp.

Rees G 1953. Some parasitic worms from fishes off the coast of Iceland. II. Trematode (Digenea). Parasitology 43: 15-26.

Rego AA 1977. Cestóides parasitas de Carcharinus longimanus (Poey, 1861). Rev Brasil Biol 37: 847852.

Rego AA, Santos JC, Silva PP 1974. Estudos de cestóides de peixes do Brasil. Mem Inst Oswaldo Cruz 72: $187-204$.

Rego AA, Vicente JJ, Santos CP, Wekid RM 1983. Parasitas de anchovas, Pomatomus saltatrix (L.) do Rio de Janeiro. Ciênc Cult 35: 1329-1336.

São Clemente SC, Gomes DC 1989a. Dasyrhynchus pacificus Robinson, 1965 (Trypanorhyncha: Dasyrhynchidae) description of the adult form. Mem Inst Oswaldo Cruz 84: 113-116. 
São Clemente SC, Gomes DC 1989b. Trypanorhyncha from sharks of southern Brazilian coast: Eutetrarhynchus vooremi sp. n. and two other species parasites of Mustelus (Pisces, Triakidae). Mem Inst Oswaldo Cruz 84: 475-481.

São Clemente SC, Gomes DC 1992. Description of the adult form of Nybelinia (Syngenis) rougetcampanae Dollfus, 1960 and some new data on $N$. (N.) bisulcata (Linton, 1889) (Trypanorhyncha: Tentaculariidae). Mem Inst Oswaldo Cruz 87: 251-255.

São Clemente SC, Gomes DC, Serra Freire NM 1991. Prevalência e intensidade de infecção de helmintos da ordem Trypanorhyncha em elasmobrânquios no litoral do Sul do Brasil. Parasitol al Día 15: 9-14.

Schmidt GD 1985. Developement and life cycles. In DWT Crompton, BB Nikol (eds), Biology of Acanthocephala, Cambridge University Press, Cambridge, p. 273-306.

Skrjabin KI, Guschanskaya LJ 1958. Ordem Azygiata La Rue, 1957. In KI Skrjabin, Trematodes from Animals and Man, Tratade of Trematodology, 14, Akad Nauk SSSR, Moscow, 934 pp. (in Russian).

Smales LR 1986. Polymorphidae (Acanthocephala) from Australian mammals with descriptions of two new species. Syst Parasitol 8: 91-100.

Tanzola RD, Guagliardo SE, Brizzola, SM, Arias MV 1997. Helminth of Porichthys porosissimus (Pisces: Batrachoidiformes) in the estuary of Bahia Blanca Argentina. Helmintologia 34: 221-227.

Threlfall W, Carvajal GL 1986. Otodistomum cestoides (van Beneden, 1871) from two species of skates taken in Chilean waters. Mem Inst Oswaldo Cruz 81: 341342.

Van Cleave HJ, Vaughn CM 1941. The trematode genus Otodistomum in North America. J Parasitol 27: 253257.

Vergara L, George-Nascimento M 1982. Contribucion al estudio del parasitismo en el congrio colorado Genypterus chilensis (Guichenot, 1848). Bol Chil Parasitol 37: 9-14.

Vicente JJ, Pinto RM 1999. Nematóides do Brasil. Nematóides de peixes. Atualização: 1985-1998. Revta Bras Zool 16: 561-610.

Vicente JJ, Rodrigues HO, Gomes DC 1985. Nematóides do Brasil. 1a. Parte: Nematóides de peixes. Atas Soc Biol Rio de Janeiro 25: 1-88.

Yamaguti S 1963. Systema Helminthum, Volume V, Acanthocephala, Interscience Publishers, Inc., New York, $423 \mathrm{pp}$.

Yamaguti S 1971. Synopsis of the Digenetic Trematodes of Vertebrates, Vols 1 and 2, Keigaku Co., Tokyo, $1074 \mathrm{pp}$.

Zdzitowiecki K 1989. New data on the morphology and distribution of two acanthocephalans, Andracantha baylisi (Zdzitowiecki, 1986) comb. nov. and Corynosoma australe Johnston, 1937. Acta Parasitol Polonica 34: 167-172.

Zdzitowiecki K, Pisano E 1996. New records of Digenea infection elasmobranch and teleost fish off Heard Island (Kerguelen, sub-region, sub-Antartic). Archiv Fish Mar Res 43: 265-272. 
